\title{
The lichens of Pukhtolova Gora (St. Petersburg, Russia)
}

\author{
Irina S. Stepanchikova ${ }^{1,2}$, Dmitry E. Himelbrant ${ }^{1,2}$, Ekaterina S. Kuznetsova ${ }^{1,2}$, \\ Sergey V. Chesnokov ${ }^{2}$, Liudmila A. Konoreva ${ }^{2,3}$, Viktoria V. Pankova ${ }^{1}$ \\ ${ }^{1}$ St. Petersburg State University, Universitetskaya emb. 7-9, 199034 St. Petersburg, Russia. \\ E-mails: stepa_ir@mail.ru, d_brant@mail.ru, igel_kuzn@mail.ru, viktoria.pankova.97@gmail.com \\ ${ }^{2}$ Laboratory of Lichenology and Bryology, Komarov Botanical Institute RAS, \\ Professor Popov St. 2, 197376 St. Petersburg, Russia. E-mail: lukinbrat@mail.ru \\ ${ }^{3}$ Polar-alpine Botanical Garden-Institute, 184250 Murmansk Region, Kirovsk. E-mail: ajdarzapov@yandex.ru
}

\begin{abstract}
The lichen diversity of the proposed protected area Pukhtolova Gora counts 252 species, including 232 lichenized, 12 lichenicolous, and 8 non-lichenized saprobic fungi. Micarea laeta, M. pusilla, and Pyrenidium actinellum s. lat. are new to North-Western European Russia; Parmelia serrana, Rhizocarpon cinereovirens, and Stereocaulon taeniarum are new to St. Petersburg. Altogether 13 species recorded in the study area are red-listed in St. Petersburg, with two of them known only from historical collections. Pukhtolova Gora is an area with a high conservation value; the lichen biota of this area is one of the richest within the city limits due to the well-preserved forest habitats.
\end{abstract}

Keywords: Isthmus karelicus, protected areas, lichen diversity, red-listed species

\section{INTRODUCTION}

The present paper continues a series of lichen inventories of the existing and proposed protected areas of St. Petersburg (see e. g., Himelbrant et al., 2005; Stepanchikova et al., 2014, 2020). The presented list of taxa comprises revised historical data and results of our own field investigations.

Pukhtolova Gora proposed protected area is a part of former Finnish socken (parish) Terijoki which was intensively studied in the past both by Russian and Finnish lichenologists. However, old labels are often not detailed enough, so only some historical records can be more or less confidently attributed to the certain territory. In 1907, the first lichen specimens from Puhtula were collected by V. P. Drobov and B. O. Kashmensky. These specimens contain several widespread macrolichens (namely, Cetraria islandica, Cladonia rangiferina, C. stellaris, Peltigera aphthosa, Pseudevernia furfuracea, and Stereocaulon tomentosum), the list was published in a small educational brochure (Vereitinov \& Kashmensky, 1907). The next lichen collection from Puhtula was made by Lars F. Fagerström, mostly in 1938, in course of his comprehensive inventory of Terijoki socken (Fagerström, 1945). In 1939, several specimens were also collected by Sten Ahlner (Ahlner, 1948). Summarizing the results obtained from critical revision of herbarium collections and literature records, a total of 34 species are known from the study area for the first half of the 20th century. The majority of them (29 species) were collected by Fagerström (1945) and Ahlner (1948).

Our field research was conducted as a part of a comprehensive inventory of biodiversity, communities, and landscapes of the proposed protected area. The obtained information is used to organize new protected areas and to refine the protective measures for existing ones. Moreover, the data on local populations of rare and endangered species will be useful for future update of the regional Red Data Book.

\section{MATERIAL AND METHODS}

\section{Study area}

The proposed protected area "Pukhtolova Gora" (Fig. 1-2) occupies an area of ca. $4 \mathrm{~km}^{2}$ in the northern part of Kurortny District of St. Petersburg, in southern vicinities of the village Reshetnikovo (former Puhtula, Terijoki) and the settlement Roschcino (Raivola), northeast of the Ushkovo railway station. According to the biogeographical subdivision of Eastern Fennoscandia (Kotiranta et al., 1998), it belongs to Isthmus karelicus (Ik). The landscape of the study area is represented by sandy plains and hills formed by Quaternary lake-glacial sediments, the highest point is the hill Pukhtolova (Bolshaya Komandnaya, Puhtulanmäki), 
$100.8 \mathrm{~m}$ a. s. 1., situated in the southeastern part of the area. Two small water bodies are located in the eastern part of the study area: Lake Ilistoe (Likolampi), ca. $0.03 \mathrm{~km}^{2}$, and a small pond.

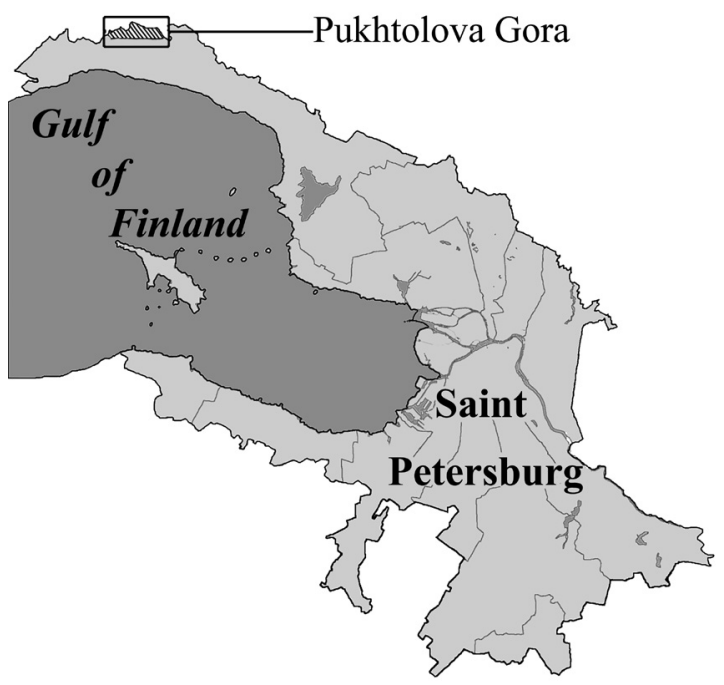

Fig. 1. The study area, Puhtolova Gora in the limits of St. Petersburg.

Pukhtolova Gora has always been relatively undisturbed area used mainly for recreation by the residents of nearby settlements and villages.
In the end of the 19th - beginning of the 20th century the territory was partly occupied by dachas (villas), and a sand pit was made in the southeastern part of the area. In 20th century military objects existed here (Khramtsov, 2021). However, most part of the area has always been covered by natural vegetation, though disturbed by local buildings, roads, and cuttings. Nowadays, the plant communities of Pukhtolova Gora are represented mainly by middle-aged pine and spruce forests, mixed stands, and swamps. The most part of the territory is a moderate recreation area, like hiking and skiing; the slope of the Pukhtolova hill and an area of former sand pit are used by ski resort.

\section{Data collection}

The material was collected in 2010 and 2020 by Irina S. Stepanchikova (IS), Dmitry E. Himelbrant (DH), and Ekaterina S. Kuznetsova (EK) within the proposed protected area Pukhtolova Gora. We investigated 16 standard sample areas (SA), of $20 \times 20 \mathrm{~m}$ (or within natural boundaries of the community if the community covered smaller area), where the lichen diversity of each substrate was described comprehensively, and 8 additional plots (AP), where only individual substrates or species were checked (Appendix 1). The specimens are deposited in H and LECB. DH, IS, EK, and Viktoria Pankova identified the

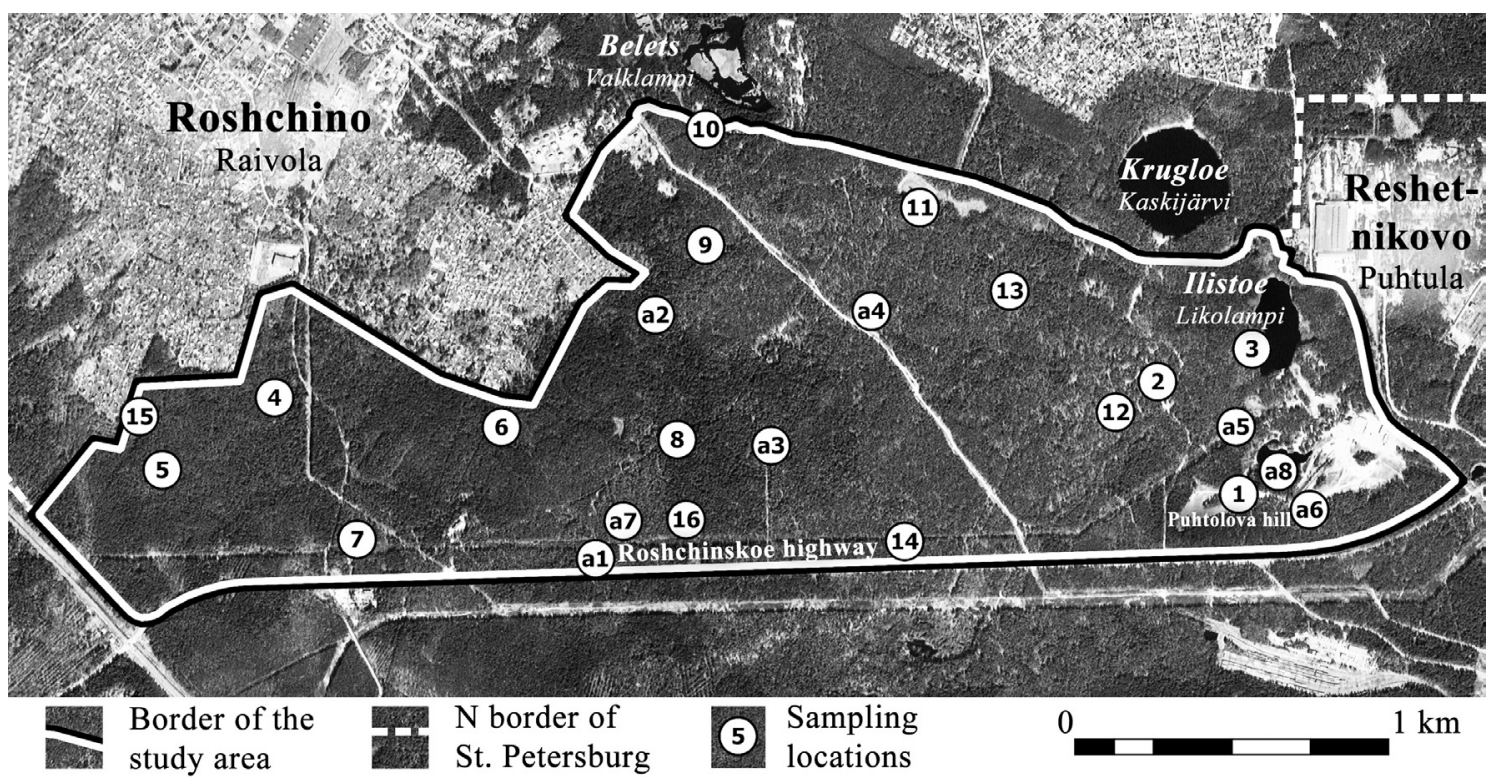

Fig. 2. The investigated locations within the study area (see Appendix 1). 
majority of specimens, Liudmila A. Konoreva and Sergey V. Chesnokov identified most of the Micarea specimens; if otherwise, the author of identification is indicated. Additionally, the material collected by Fagerström (LF), Ahlner, Kashmensky \& Drobov in vicinity of Puhtula was revised (herbaria H, S, and LE, respectively); such data are given in the species list without indication of the locality.

In the species list the nomenclature of taxa generally follows Nordin et al. (2011). For each species the substrates and localities are listed. Species new to St. Petersburg (and not known in the Leningrad Region) or larger regions are supplied with information on diagnostic characteristics and distribution in North-Western European Russia, Fennoscandia and the Baltic countries. Lichen substances are given for HPTLC-analyzed species. Chromatography was performed according to standard techniques of high performance thin-layer chromatography using solvent system C (Orange et al., 2001).

In the species list the following symbols and abbreviations are used:

(a) ecological groups of fungi: \# - lichenicolous fungi and protists, (\#) - facultatively lichenicolous fungi, + - non-lichenized fungi;

(b) noteworthy records: ! - regionally protected species (Red..., 2018), §- habitat specialists, * - indicator species (Andersson et al., 2009), $\dagger-$ species known from historical data only;

(c) regions: LR - Leningrad Region, WLR - Western Leningrad Region, $\mathrm{SPb}$ - St. Petersburg;

(d) frequency of occurrence for the species collected in 2010-2020 by the authors: $\left[R_{1}\right]$ - single record (the species was found once), $[R]$ - rare (the species was recorded in 2-3 SA, i.e. up to $20 \%$ of the total number of SA or more than in one additional plot), [O] - occasionally (in 4-6 SA, up to 40\%), $[\mathrm{F}]$ - frequent (in 7-9 SA, up to 60\%), [C] common (in 10-12 SA, up to $80 \%$ ), [VC] very common (in 13-16 SA, over $80 \%$ );

(e) abbreviations of the collectors' names - see above.

\section{RESULTS \& DISCUSSION}

The species

Absconditella delutula (Nyl.) Coppins \& H. Kilias - on plant debris; $2\left[R_{1}\right]$.
Absconditella lignicola Vězda \& Pišút - on wood of Picea abies (L.) Karst.; 8 [R $]$.

ACAROSPORA FUSCATA (Schrad.) Th. Fr. - on granite; 7, 9, 12 [R].

ACAROSPORA GLAUCOCARPA (Ach.) Körb. - on granite and concrete; 2, 7, 9, 10, a1 [O].

ACAROSPORA MOENIUM (Vain.) Räsänen - on concrete; 2 , a $1[R]$.

!† ANAPTYCHIA CILIARIS (L.) Körb. - coll. LF: on bark of Populus tremula L., 09.06.1938 (Fagerström, 1945; H 8003920). EN, 2 (Red..., 2018).

ANISOMERIDIUM POLYPORI (Ellis \& Everh.) M. E. Barr - on bark of Populus tremula; $15\left[\mathrm{R}_{1}\right]$.

\# ARTHONia BIATORICOLA Ihlen \& Owe-Larss. - on thallus of Biatora pallens on branches of young Picea abies; a8 $\left[\mathrm{R}_{1}\right]$.

!* ARTHonia helvola (Nyl.) Nyl. - on wood of Picea abies; $6\left[\mathrm{R}_{1}\right]$. NT, 4 (Red..., 2018).

ARTHONia MEDiElla Nyl. - on bark of Populus tremula; $14\left[\mathrm{R}_{1}\right]$.

ARTHONIA PUNCTIFORMIS Ach. - on bark of Betula sp. and Populus tremula; 12, 15 [R].

AsPicilia CineREa (L.) Körb. - on granite; 12 [ $\left.\mathrm{R}_{1}\right]$.

ATHALlia CERINELlOIDEs (Erichsen) Arup et al. - on bark of Populus tremula; $2\left[\mathrm{R}_{1}\right]$.

Athallia holocarpa (Hoffm.) Arup et al. - on concrete; $2\left[\mathrm{R}_{1}\right]$.

Athallia PYRACEA (Ach.) Arup et al. - on bark of Populus tremula; 2, 12, 14, 15 [O].

BACIDIA ARCEUtina (Ach.) Arnold - on bark of Populus tremula; $2\left[\mathrm{R}_{1}\right]$.

Bacidina Chloroticula (Nyl.) Vězda \& Poelt - on bark of Acer platanoides L. and Vaccinium myrtillus L. on brick; 12, 15 [R].

BACIDINA MODESTA (Zwackh ex Vain.) S. Ekman on bark of Padus avium Mill.; 15 [ $\left.\mathrm{R}_{1}\right]$.

BAEOMYCES CARNEUs Flörke - on sand; $1\left[\mathrm{R}_{1}\right]$.

BAeOmyces RUfus (Huds.) Rebent. - on granite, sand and soil; 1, 2, 10, 12 [O].

Biatora CHRYsantha (Zahlbr.) Printzen - on bark of Sorbus aucuparia L.; 8 [R $\left.\mathrm{R}_{1}\right]$.

BiATORA EFFLOREsCENs (Hedl.) Räsänen - on bark of Acer platanoides, Betula sp., Padus avium, 
Populus tremula, and Sorbus aucuparia; 8, 12, 14-16 [O].

Biatora HELVOLA Körb. ex Hellb. - on bark of Salix sp.; $3\left[\mathrm{R}_{1}\right]$.

BiATORA OCELliformis (Nyl.) Arnold - on bark of Pinus sylvestris L.; $1\left[\mathrm{R}_{1}\right]$.

Biatora Pallens (Kullh.) Printzen - on bark of Picea abies; a8 $\left[\mathrm{R}_{1}\right]$.

BILIMBia MicROCARPA (Th. Fr.) Th. Fr. - on concrete roof of the blindage; $7\left[\mathrm{R}_{1}\right]$.

Bilimbia SABUlETORUm (Schreb.) Arnold - on clayey soil; $7\left[\mathrm{R}_{1}\right]$.

BRYORIA CAPILLARIS (Ach.) Brodo \& D. Hawksw. on bark of Pinus sylvestris; $1\left[\mathrm{R}_{1}\right]$. Coll. LF: on bark of Sorbus aucuparia, 09.06.1938 (H 8003300, sub Pseudevernia furfuracea).

BRYORIA FUSCESCENS (Gyeln.) Brodo \& D. Hawksw. on bark of Betula sp., Pinus sylvestris, Populus tremula, Salix sp., and Sorbus aucuparia, on wood of Pinus sylvestris; 1, 2, 14 [R].

Buellia GRISEOviREns (Turner \& Borrer ex Sm.) Almb. - on bark of Alnus incana (L.) Moench, Betula sp., Populus tremula, and Sorbus aucuparia; 11, 12, 14, 15 [O].

Calicium glaucellum Ach. - on wood of Pinus sylvestris; $11\left[\mathrm{R}_{1}\right]$.

CALICIUM PINASTRI Tibell - on bark of Pinus sylvestris; $5,9,12[R]$.

Calicium trabinellum (Ach.) Ach. - on wood of Pinus sylvestris; $11\left[\mathrm{R}_{1}\right]$.

Caloplaca cerina (Hedw.) Th. Fr. - on bark of Populus tremula; $15\left[\mathrm{R}_{1}\right]$. Coll. LF: on bark of Populus balsamifera L., 09.06.1938 (H 8005539, sub Physconia distorta).

Candelariella efFlorescens R. C. Harris $\&$ W. R. Buck - on bark of Populus tremula; 14, 15 [R].

CANDELARIELla lutella (Vain.) Räsänen - on bark of Populus tremula; $2\left[\mathrm{R}_{1}\right]$.

CANDElariella Reflexa (Nyl.) Lettau - on bark of Populus tremula; $12\left[\mathrm{R}_{1}\right]$.

Candelariella Xanthostigma (Ach.) Lettau - on bark of Populus tremula; 12, 14 [R].

Catillaria nigroclavata (Nyl.) Schuler - on bark of Populus tremula; 2, 3, 14 [R].
Cetraria islandica (L.) Ach. subsp. islandica - on bark and wood of Pinus sylvestris, on sandy soil; 1, 2, 9, 12, 14, a2, a3 [O]. Coll. B. O. Kashmensky (Vereitinov \& Kashmensky, 1907).

Cetraria sepincola (Ehrh.) Ach. - on bark of Betula sp., Pinus sylvestris, Populus tremula, and Salix sp., on wood of Pinus sylvestris; 1-3, $11,12,14$ [O].

Cetrariella commixta (Nyl.) A. Thell \& Kärnefelt on granite; a4 $\left[R_{1}\right]$.

Chaenotheca chrysocephala (Turner ex Ach.) Th. Fr. - on bark of Picea abies; $16\left[\mathrm{R}_{1}\right]$.

Chaenotheca ferruginea (Turner ex Sm.) Mig. on bark of Betula sp., Picea abies, and Pinus sylvestris; 4, 6, 8, 16 [O].

!* Chaenotheca stemonea (Ach.) Müll. Arg. - on wood of Picea abies; 16 [R ${ }_{1}$. VU, 3 (Red..., 2018).

Chaenotheca trichialis (Ach.) Th. Fr. - on wood of Pinus sylvestris; 5, 11 [R].

Chaenotheca Xyloxena Nádv. - on wood of Pinus sylvestris; $9\left[\mathrm{R}_{1}\right]$.

\#* Chaenothecopsis epithallina Tibell - on thallus of Chaenotheca trichialis on wood of Pinus sylvestris; $5\left[\mathrm{R}_{1}\right]$.

+* Chaenothecopsis nigra Tibell - on bark of Picea abies; $16\left[\mathrm{R}_{1}\right]$.

+ Chaenothecopsis pusilla (Ach.) A. F. W. Schmidt - on wood of Pinus sylvestris; $5\left[\mathrm{R}_{1}\right]$.

$(\#)^{*}$ Chaenothecopsis pusiola (Ach.) Vain. - on thallus of Chaenotheca xyloxena on standing deadwood of Pinus sylvestris; 9 [ $\left.\mathrm{R}_{1}\right]$.

\#§ Chaenothecopsis subParoica (Nyl.) Tibell - on thallus of Haematomma ochroleucum var. ochroleucum on bark of Betula sp.; 2, 12 [R].

Cladonia arbuscula (Wallr.) Flot. subsp. ARBusCULA - on bark of Pinus sylvestris, on wood, and sandy soil; 1-3, 9, 10, 14, a7 [O].

Cladonia Bacilliformis (Nyl.) Sarnth. - on bark of Betula sp. and Pinus sylvestris, on wood; 2, 3, 5, 9-13 [F].

! Cladonia Bellidiflora (Ach.) Schaer. - on sand; $1\left[R_{1}\right]$. NT, 4 (Red..., 2018).

Cladonia botrytes (K. G. Hagen) Willd. - on bark of Picea abies and Pinus sylvestris, on wood; 1 , 3, 9-12, 16 [F]. 
Cladonia caespiticia (Pers.) Flörke - on bark of Betula sp. and Picea abies; 4, 6 [R].

Cladonia Carneola (Fr.) Fr. - on wood of Pinus sylvestris; 3, 13 [R].

Cladonia Cenotea (Ach.) Schaer. - on bark of Betula sp. and Pinus sylvestris, on wood, on primary soil; 1-5, 9-15 [C].

Cladonia Chlorophaea (Flörke ex Sommerf.) Spreng. s. lat. - on bark of Betula sp., Juniperus communis L., Picea abies, Pinus sylvestris, Populus tremula, and Sorbus aucuparia, on wood, soil and decaying leather; 1-10, 12-16 [VC].

Cladonia coniocraea (Flörke) Spreng. - on bark of Betula sp., Picea abies, Pinus sylvestris, and Populus tremula, on wood of conifers, soil, and decaying leather; 1-10, 12, 14-16 [VC].

Cladonia Cornuta (L.) Hoffm. subsp. CORnUTA - on bark of Betula sp., Picea abies, Pinus sylvestris, and Populus tremula, on wood and soil; 2, 5, 8-10, 12-14 [F].

Cladonia CRISPATA (Ach.) Flot. var. CRISPATA - on bark of Betula sp. and Pinus sylvestris, on wood and soil; 1, 2, 9, 10, 12-14; var. CETRARIIFORMIS (Delise) Vain. - on bark of Pinus sylvestris; 1, 9. [F].

Cladonia deformis (L.) Hoffm. - on bark of Betula sp. and Pinus sylvestris, on wood of Pinus sylvestris, on soil; 1, 2, 9-13 [F].

Cladonia digitata (L.) Hoffm. - on bark of Betula sp., Picea abies, and Pinus sylvestris, on wood of Pinus sylvestris; 1, 4-6, 12, 13, 16 [F].

Cladonia fimbriata (L.) Fr. - on bark of Betula sp., Juniperus communis, Picea abies, Pinus sylvestris, and Sorbus aucuparia, on wood of conifers, on soil; 2, 4-6, 8, 10-14 [C].

Cladonia FURCATA (Huds.) Schrad. - on sand and soil; 1, 2, 10, 12, 14, a3 [O].

Cladonia gracilis (L.) Willd. subsp. turbinata (Ach.) Ahti - on bark of Betula sp. and Pinus sylvestris, on wood and soil; 1, 2, 9, 10, 13, 14 [O].

Cladonia MACILENTA Hoffm. - on bark and wood of Pinus sylvestris, on primary soil; 1, 5, 9-14, a6 $[\mathrm{F}]$.

Cladonia Mitis Sandst. - on bark of Pinus sylvestris, on sandy soil; 1, 2, 9, 13 [O].

!* Cladonia noRvegica Tønsberg \& Holien - on wood of Picea abies (log); 16 [R $]$. EN, 2 (Red..., 2018).
Cladonia OCHROCHLORA Flörke - on bark of Pinus sylvestris and on burnt wood; 4, 10 [R].

Cladonia PHyllophora Hoffm. - on soil; 2, 14, a3 [R].

Cladonia Pleurota (Flörke) Schaer. - on bark of Pinus sylvestris; $9\left[\mathrm{R}_{1}\right]$.

Cladonia pyxidata (L.) Hoffm. - on soil; 2 [ $\left.R_{1}\right]$.

Cladonia RANGiferina (L.) F. H. Wigg. - on bark of Betula sp. and Pinus sylvestris, on wood, and sandy soil; 1-3, 9, 10, 12-14, a7 [F]. Coll. B. O. Kashmensky (Vereitinov \& Kashmensky, 1907).

Cladonia REI Schaer. - on burnt wood, soil, and mosses; 2, 7, 10 [R].

! Cladonia stellaris (Opiz) Pouzar \& Vězda on sand; a7 $\left[R_{1}\right]$. Coll. V. P. Drobov \& B. O. Kashmensky: on soil, 25.03.1907 (Vereitinov \& Kashmensky, 1907; LE L-10652). EN, 2 (Red..., 2018).

Cladonia subulata (L.) F. H. Wigg. - on burnt wood and on soil; 2, 10 [R].

Cladonia sulphurina (Michx.) Fr. - on bark and wood of Pinus sylvestris, on sandy soil; 1, 5, 9, $10,13[\mathrm{O}]$.

Cladonia uncialis (L.) F. H. Wigg. subsp. UnCialis - on bark of Betula sp. and on soil; 2, 12; subsp. BIUNCIALIS (Hoffm.) M. Choisy - on soil; 12. [R].

Cladonia verticillata (Hoffm.) Schaer. - on sandy soil; 1, 2, 10 [R].

Clypeococcum hypocenomycis D. Hawksw. - on thallus of Hypocenomyce scalaris on bark of Picea abies and Pinus sylvestris; 9, 12 [R].

Coenogonium Pineti (Ach.) Lücking \& Lumbsch - on bark of Betula sp., Picea abies, Pinus sylvestris, and Vaccinium myrtillus, on wood of Picea abies and on fruit bodies of polypores; 4-6, 8, $15,16[\mathrm{O}]$.

Dibaeis baeomyces (L. f.) Rambold \& Hertel - on soil; $2\left[\mathrm{R}_{1}\right]$.

\# Epilichen scabrosus (Ach.) Clem. - on sand; $1\left[\mathrm{R}_{1}\right]$.

$\dagger$ Evernia MESOMORPHA Nyl. - coll. LF: on bark of Betula sp., 09.06.1938 (Fagerström, 1945; H 8003299); coll. S. Ahlner: on bark of Pinus sylvestris, 20.08.1939 (Ahlner, 1948; S L-37425). 
EVERnia PRUNASTRI (L.) Ach. - on bark of Padus avium, Populus tremula, and Sorbus aucuparia, on wood; 3, 12, 14, 15 [O]. Coll. LF: on bark of Sorbus aucuparia, 09.06.1938 (H 8004994).

Fellhanera subtilis (Vězda) Diederich \& Sérus. on bark of Vaccinium myrtillus; $5\left[\mathrm{R}_{1}\right]$.

Frutidella furfuracea (Anzi) M. Westb. \& M. Svensson - on bark of Pinus sylvestris and Populus tremula; 9, 12, 13 [R].

Fuscidea PUsilla Tønsberg - on bark of Alnus incana, Betula sp., Juniperus communis, Padus avium, Picea abies, Pinus sylvestris and Sorbus aucuparia, on wood of conifers; 1-3, 6, 8, 9, 11, $12,14-16[\mathrm{C}]$.

GRAPHIS SCRIPTA (L.) Ach. - on bark of Sorbus aucuparia; $8\left[\mathrm{R}_{1}\right]$.

HAEMATOMMA OCHROLEUCUM (Neck.) J. R. Laundon var. OCHROLEUCUM - on bark of Betula sp. and Picea abies; 2, 9, 12 [R].

\# Heterocephalacria physciacearum (Diederich) Millanes \& Wedin - on thallus of Physcia aipolia on bark of Populus tremula; $14\left[\mathrm{R}_{1}\right]$.

Hypocenomyce scalaris (Ach.) M. Choisy - on bark of Betula sp., Picea abies, and Pinus sylvestris, on wood of conifers; 1-4, 6, 8-14, 16 [VC].

HyPOGYMNIA FARINACEA Zopf - on bark of Pinus sylvestris; $1\left[\mathrm{R}_{1}\right]$.

HyPogymia PHYSODEs (L.) Nyl. - on bark of coniferous and deciduous trees, wood, and granite; 1-16 [VC]. Coll. LF: on bark of Betula sp. and Sorbus aucuparia, 09.06.1938 (H 8005427, 8003299).

Hypogymia tubulosa (Schaer.) Hav. - on bark of coniferous and deciduous trees, wood, and granite; 1-5, 7-9, 11, 12, 14, 15 [C]. Coll. LF: on bark of Sorbus aucuparia, 09.06.1938 (Fagerström, 1945; H 8005088).

\# IlLOSPORIOPSIS CHRISTIANSENII (B. L. Brady \& D. Hawksw.) D. Hawksw. - on thallus of Physcia aipolia on bark of Populus tremula; 12, 15 [R].

IMSHAUGiA ALEURITES (Ach.) S. L. F. Meyer - on bark of Pinus sylvestris and on wood of Picea abies; 1, 16 [R].

JAPEWIA SUBAURIFERA Muhr \& Tønsberg - on bark of Picea abies and Pinus sylvestris; 4, 5, 8, 9, $16[\mathrm{O}]$.
LeCANia CyRTElla (Ach.) Th. Fr. - on bark of Populus tremula and Sorbus aucuparia; 2, 14 [R].

LECANIA CYRTELLINA (Nyl.) Sandst. - on bark of Populus tremula; $15\left[\mathrm{R}_{1}\right]$.

LeCania naegeli (Hepp) Diederich \& van den Boom - on bark of Betula sp. and Populus tremula; 2, 14 [R].

LECANORA AITEMA (Ach.) Hepp - on bark and wood of Pinus sylvestris; 1, 9 [R].

LeCANORa AlBellula (Nyl.) Th. Fr. - on bark of Betula sp. and Salix sp.; 2, 14 [R].

LECANORA Allophana Nyl. - on bark of Populus tremula; 2, 3, 12, 14, 15 [O].

LECANORA ARgENTATA (Ach.) Malme - on bark of Populus tremula; 2, 12, 14 [R].

LECANORA CAdubriae (A. Massal.) Hedl. - on bark and wood of Pinus sylvestris; 11, 12 [R].

LECANORA CARPINEA (L.) Vain. - on bark of Padus avium, Populus tremula, and Sorbus aucuparia; 3, 12, 14, 15 [O]. Coll. LF: on bark of Populus balsamifera and Sorbus aucuparia, 09.06.1938 (H 8005427, sub Melanelixia subaurifera; H 8005501, sub Physcia stellaris).

LECANORA CHLAROTERA Nyl. - on bark of Acer platanoides, Padus avium, Populus tremula, and Sorbus aucuparia; 2, 3, 5, 15 [O].

LECANORA HYPOPTELLA (Nyl.) Grummann - on bark of Pinus sylvestris and on wood of Picea abies; $1,2,8,9,14[\mathrm{O}]$.

LECANORA INTRICATA (Ach.) Ach. - on granite; 7, $10,12[R]$.

LECANORA POLYTROPA (Ehrh. ex Hoffm.) Rabenh. on granite; 9, $10[\mathrm{R}]$.

LECANORA POPUlicola (DC.) Duby - on bark of Populus tremula; 12, 15 [R].

LECANORA PULICARIS (Pers.) Ach. - on bark of $A l$ nus incana, Betula sp., Corylus avellana (L.) H. Karst., Juniperus communis, Pinus sylvestris, Populus tremula, Salix sp., and Sorbus aucuparia; 1-4, 12, 14, $15[\mathrm{~F}]$.

LECANORA SUbintricata (Nyl.) Th. Fr. - on bark of Pinus sylvestris and Sorbus aucuparia; 5, 11, 14 [R].

LeCANora symmicta (Ach.) Ach. - on bark of Padus avium, Pinus sylvestris, Populus tremula, 
and Salix sp., on wood of conifers; $1-3,8,11$, $12,14,15[\mathrm{~F}]$.

LECANORA UMBrina (Ach.) A. Massal. - on bark of Populus tremula and Salix sp.; 2, 3, 12, 15 [O].

LECIDEA NYLANDERI (Anzi) Th. Fr. - on bark of Betula sp., Padus avium, Picea abies, Pinus sylvestris, and Sorbus aucuparia, on wood of Pinus sylvestris; 1, 2, 4-6, 8, 9, 11-16 [VC].

Lecidea turgidula Fr. - on bark of Pinus sylvestris and on wood of conifers; 4, 5, 11, 13, 16 [O].

Lecidella elaeochroma (Ach.) M. Choisy - on bark of Padus avium, Populus tremula, and Sorbus aucuparia; 2, 12, 14, 15 [O].

LECIDELLA EUPHOREA (Flörke) Hertel - on bark of Populus tremula; 2, 15 [R].

LECIDELLA MEIOCOCCA (Nyl.) Leuckert \& Hertel - on granite; $7\left[\mathrm{R}_{1}\right]$.

LEPRARIA ELOBATA Tønsberg - on bark of Alnus incana, Betula sp., Corylus avellana, Juniperus communis, Picea abies, Pinus sylvestris, and Sorbus aucuparia, on granite and sandy soil; 1 , 4, 6, 8, 10, 14-16 [F].

LEPRARIA INCANA (L.) Ach. - on bark of Betula sp., Juniperus communis, Picea abies, Pinus sylvestris, Populus tremula, and Sorbus aucuparia, on wood of Picea abies; 1-6, 8, 12-16 [C].

LEPRARIA JACKII Tønsberg s. lat. - on bark of Betula sp., Juniperus communis, Picea abies, and Pinus sylvestris; 1, 6, 8, 14, 16 [O].

LEPRARIA LOBIFICANS Nyl. - on bark of Betula sp., Picea abies, and Pinus sylvestris; 6, 12, 16 [R].

LEPRARIA NEGLECTA (Nyl.) Lettau - on granite and mosses; 9, 12, a4 [R]. Thalli contain alectorialic acid.

LEPTORHAPHIS ATOMARIA (Ach.) Szatala - on bark of Populus tremula; 3, 15 [R].

+ LePtorhaphis EPIDERMidis (Ach.) Th. Fr. - on bark of Betula sp.; 9, 14 [R].

\# Licea parasitica (Zukal) G. W. Martin - on thallus of Physcia aipolia on bark of Populus tremula; $14\left[\mathrm{R}_{1}\right]$.

\# Lichenoconium erodens M. S. Christ. \& D. Hawksw. - on thallus of Hypogymnia physodes on bark of Pinus sylvestris; $12\left[\mathrm{R}_{1}\right]$.
Loxospora elatina (Ach.) A. Massal. - on bark of Picea abies; $8\left[\mathrm{R}_{1}\right]$. Coll. S. Ahlner: on bark of Pinus sylvestris, 20.08.1939 (S F-138936).

MelaneliXia subaurifera (Nyl.) O. Blanco et al. on bark of Acer platanoides, Padus avium, Populus tremula, Salix sp., and Sorbus aucuparia; 2, 12, 15 [R]. Coll. LF: on bark of Sorbus aucuparia, 09.06.1938 (H 8005427).

Melanohalea exasperata (De Not.) O. Blanco et al. - on bark of Populus tremula; $15\left[\mathrm{R}_{1}\right]$.

Melanohalea exasperatula (Nyl.) O. Blanco et al. on bark of Betula sp., Pinus sylvestris, Populus tremula and Sorbus aucuparia; 1, 2, 12, 15 [O].

Melanohalea olivacea (L.) O. Blanco et al. - on bark of Populus tremula and Sorbus aucuparia; 12, 14 [R]. Coll. LF: on bark of Sorbus aucuparia, 09.06.1938 (H 8003302, sub Pseudevernia furfuracea).

Micarea byssacea (Th. Fr.) Czarnota et al. - on bark of Betula sp. and Picea abies; 6, 9, 16 [R]. Thalli contain methoxymicareic acid.

Micarea DENigRata (Fr.) Hedl. - on bark and wood of Pinus sylvestris, on wood of Picea abies; 1, 5, 9, 12 [O]. Thalli contain gyrophoric acid.

MicAREA ERRATICA (Körb.) Hertel et al. - on granite; $1,9[\mathrm{R}]$.

Micarea laEta Launis \& Myllys - on wood of Picea abies; 4, 8 [R]. Thalli contain methoxymicareic acid. - New to North-Western European Russia (see also Himelbrant et al., 2021). Distribution in Fennoscandia and Baltic countries: Sweden and Finland (Launis et al., 2019; Kantelinen et al., 2021). The species belongs to Micarea prasina group. Characterized by usually granular or almost continuous vivid green to olive-green thallus composed of goniocysts, adnate, cream-white or sometimes brownish, usually numerous apothecia, K- (no Sedifolia-grey), ellipsoid 0-1-septate ascospores 3-4 $\mathrm{\mu m}$ wide, and production of methoxymicareic acid (Kantelinen et al., 2021).

Micarea melaena (Nyl.) Hedl. - on bark of Betula sp. and Pinus sylvestris, on wood of Pinus sylvestris; $1,4-6,8,14,16[\mathrm{~F}]$.

MiCAREA cf. MICROAREOLATA Launis et al. - on bark of Betula sp. and Vaccinium myrtillus; 5, 8 [R]. The specimens are fully consistent with the description by morphology and anatomy, but they are too small to be analyzed by TLC. 
MiCAREA NiTSChKEANA (J. Lahm ex Rabenh.) Harm. on bark of Betula sp. and Corylus avellana, also on wood of Pinus sylvestris; 1, 4, 13 [R]. Thalli contain gyrophoric acid.

MicAREA PRASINA Fr. s. str. - on bark of Picea abies and on wood of Pinus sylvestris; 4-6, 12 [O]. Thalli contain micareic acid.

MicAREA PUSILla Launis et al. - on bark of Betula sp.; $12\left[\mathrm{R}_{1}\right]$. Thallus contains methoxymicareic acid. - New to North-Western European Russia (see also Himelbrant et al., 2021). Characterized by whitish green to olive green, usually inconspicuous, membranous, or warted-granular thallus, numerous, very small creamy or white apothecia, and small inconspicuous pycnidia, along with production of methoxymicareic acid (Launis et al., 2019).

! $\S^{+}$Microcalicium ahlneri Tibell - on bark and wood of Picea abies; 6, 16 [R]. CR, 1 (Red..., 2018).

! Montanelia sorediata (Ach.) Divakar et al. - on granite; $12\left[\mathrm{R}_{1}\right]$. VU, 3 (Red..., 2018).

Mycobilimbia CARneOAlBida (Müll. Arg.) S. Ekman \& Printzen - on mosses; $15\left[\mathrm{R}_{1}\right]$.

MycoBILIMBIA EPIXANTHOIDEs (Nyl.) Vitik. et al. - on wood of Picea abies and on mosses; 8, 15 [R].

! Mycoblastus sanguinarius (L.) Norman - on bark of Picea abies; 16 [R $\left.{ }_{1}\right]$. CR, 1 (Red..., 2018).

+ Mrcocalicium subtile (Pers.) Szatala - on wood of Picea abies and Pinus sylvestris; 1, 2, 5, 9, $11-13,16[\mathrm{~F}]$.

Myriolecis HAgeniI (Ach.) Śliwa et al. - on bark of Populus tremula and Salix sp.; 2, 3, 15 [R].

NAETROCYMBE PUNCTIFORMis (Pers.) R. C. Harris on bark of Sorbus aucuparia; $14\left[\mathrm{R}_{1}\right]$.

OCHROLECHIA MICROSTICTOIDES Räsänen - on bark of Betula sp.; 16 [R $]$.

Palicella filamentosa (Stirt.) Rodr. Flakus \& Printzen - on bark and wood of Pinus sylvestris; $1,12[R]$.

PARMElia SERRANA A. Crespo et al. - on bark of Betula sp.; $6\left[\mathrm{R}_{1}\right]$.

Parmelia sulcata Taylor - on bark of Acer platanoides, Alnus incana, Betula sp., Malus domestica Borkh., Padus avium, Picea abies, Populus tremula, Salix sp., and Sorbus aucuparia, on wood; $1-3,12,14-16$ [F]. Coll. LF: on bark of Acer platanoides, Populus balsamifera, and Sorbus aucuparia, 09.06.1938 (H 8000478, $8000479,8003302,8003697,8004994$, 8005501).

PARMeliopsis Ambigua (Wulfen) Nyl. - on bark of coniferous and deciduous trees, on wood and granite; 1-9, 11-16 [VC].

PARMEliopsis hyPEROPTA (Ach.) Arnold - on bark of Betula sp., Juniperus communis, Picea $a b$ ies, Pinus sylvestris, Populus tremula, Sorbus aucuparia, and Vaccinium myrtillus, on wood of Pinus sylvestris and on granite; 1, 2, 4-9, 11-14 [C].

! Peltigera Aphthosa (L.) Willd. - on soil; a3 [ $\left.\mathrm{R}_{1}\right]$. Coll. B. O. Kashmensky (Vereitinov \& Kashmensky, 1907). EN, 2 (Red..., 2018).

Peltigera Canina (L.) Willd. - on bark of Populus tremula and on soil; 2, 12, 14 [R].

Peltigera didactyla (With.) J. R. Laundon - on soil; 2, 10, a1 [R].

Peltigera extenuata (Nyl. ex Vain.) Lojka - on soil; a4 $\left[R_{1}\right]$.

Peltigera malacea (Ach.) Funck - on soil; 7 [ $\left.R_{1}\right]$. PELTigera PRAETEXTATA (Flörke ex Sommerf.) Zopf - on soil; $2\left[\mathrm{R}_{1}\right]$.

Peltigera Rufescens (Weiss) Humb. - on soil; $7,12[R]$.

Pertusaria CARneopallida (Nyl.) Anzi ex Nyl. - on bark of Sorbus aucuparia; 8 [R $]$.

Phaeophyscia ciliata (Hoffm.) Moberg - on bark of Populus tremula; 15 [R $]$. Coll. LF: on bark of Populus balsamifera, 09.06.1938 (H 8000707).

PhaEophyscia orbicularis (Neck.) Moberg - on bark of Populus tremula; 2, 15 [R].

Phlyctis ARgena (Spreng.) Flot. - on bark of Acer platanoides, Alnus incana, Padus avium, Populus tremula, and Salix sp.; 3, 12, 15 [R].

Physcia ADSCEndens H. Olivier - on bark of $\mathrm{Ma}$ lus domestica, Populus tremula, Salix sp., and Sorbus aucuparia, on concrete; 2, 3, 12, 14, 15 [O].

Physcia Aipolia (Ehrh. ex Humb.) Fürnr. - on bark of Populus tremula, Salix sp., and Sorbus aucuparia; 2, 3, 12, 14, 15 [O]. 
PHYSCIA DUBIA (Hoffm.) Lettau - on granite; $7\left[\mathrm{R}_{1}\right]$.

Physcia STEllaris (L.) Nyl. - on bark of Populus tremula; $15\left[\mathrm{R}_{1}\right]$. Coll. LF: on bark of Populus balsamifera, 09.06.1938 (H 8005501).

Physcia tenella (Scop.) DC. - on bark of Populus tremula, Salix sp., and Sorbus aucuparia; 2, 3, $12,14,15$ [O].

PhysConia DISTORTA (With.) J. R. Laundon - on bark of Populus tremula; 14, 15 [R]. Coll. LF: on bark of Populus balsamifera, 09.06.1938 (H 8005539).

Physconia enteroxantha (Nyl.) Poelt - on bark of Populus tremula; $14\left[\mathrm{R}_{1}\right]$.

Placynthiella dasaea (Stirt.) Tønsberg - on bark of Picea abies, wood of conifers, and sandy soil; 1, 2, 4, 11, 12, 16 [O].

Placynthiella icmalea (Ach.) Coppins \& P. James on bark of Betula sp., wood, sandy soil, and plant debris; 1-3, 5, 7, 8, 10, 12, $14[\mathrm{~F}]$.

Placynthiella uliginosa (Schrad.) Coppins \& P. James - on wood of Pinus sylvestris, sandy soil, plant debris, and leather; 1, 2, 5, 7, 10, a5 [O].

Platismatia glauca (L.) W. L. Culb. \& C. F. Culb. on bark of Acer platanoides, Betula sp., Juniperus communis, Padus avium, Picea abies, Pinus sylvestris, Populus tremula, Salix sp., and Sorbus aucuparia, on wood and granite; 1-9, 11-16 [VC]. Coll. LF: on bark of Acer platanoides, 09.06.1938 (H 8005558).

Polycauliona POlycarpa (Hoffm.) Frödén et al. on bark of Betula sp., Malus domestica, Populus tremula, Salix sp., Sorbus aucuparia; 3, 12, 14 [R].

Porpidia CRUstulata (Ach.) Hertel \& Knoph - on bark and wood of Pinus sylvestris and on granite; 1, 2, 9, 10, a4 [O].

PorPidia MACROCARPa (DC.) Hertel \& A. J. Schwab on granite; 1, 7, 10, 12 [O].

PORPIDIA SOREDIZODEs (Lamy ex Nyl.) J. R. Laundon - on brick; $12\left[\mathrm{R}_{1}\right]$.

Porpidia tuberculosa (Sm.) Hertel \& Knoph - on granite; a4 $\left[R_{1}\right]$.

Protothelenella corrosa (Körb.) H. Mayrhofer $\&$ Poelt - on granite; 12, a4 [R].
Protothelenella Petri H. Mayrhofer \& Poelt - on mosses; $12\left[\mathrm{R}_{1}\right]$.

Pseudevernia furfuracea (L.) Zopf - on bark of Betula sp., Picea abies, Pinus sylvestris, Populus tremula, and Salix sp., on wood; 1-3, 5, 9, 11, 13-16 [C]. Coll. LF: on bark of Sorbus aucuparia, 09.06.1938 (Fagerström, 1945; H 8003299, 8003300, 8003302); coll. B. O. Kashmensky (Vereitinov \& Kashmensky, 1907).

Pseudoschismatomma Rufescens (Pers.) Ertz \& Tehler - on bark of Populus tremula; $15\left[\mathrm{R}_{1}\right]$.

Psilolechia Clavulifera (Nyl.) Coppins - on bark of Picea abies; $8\left[\mathrm{R}_{1}\right]$.

PyCNORA SOROPHORA (Vain.) Hafellner - on bark and wood of Pinus sylvestris; 3, 9, 11-13 [O]. Coll. S. Ahlner: on bark of Pinus sylvestris, 20.08.1939 (S F-138936, sub Loxospora elatina).

\# Pyrenidium actinellum Nyl. s. lat. - on thallus of Baeomyces carneus on small siliceous stone; $1\left[R_{1}\right]$. - New to North-Western European Russia, the nearest locality in North-Western Russia is known in Komi Republic (Zhurbenko, 2004). Distribution in Fennoscandia and Baltic countries: Norway, Sweden, and Finland (Nordin et al., 2011). The species is characterized by immersed to almost sessile perithecioid ascomata, $0.15-0.23 \mathrm{~mm}$ in diam., sometimes aggregated in necrotic patches or gall-like deformations of the host thallus; ascospores ellipsoid to broadly fusiform, brown, (1-)3-septate, \pm constricted at the septa (for the detailed description see Navarro-Rosines \& Roux, 2007; Zhurbenko \& Pino-Bodas, 2017; Huanraulek et al., 2019). By anatomy and morphology, our specimen is consistent with the description of Pyrenidium actinellum s. str. However, by host it differs from the type material, which was associated with Scytinium teretiusculum. The lichenicolous fungus Pyrenidium actinellum s. lat. is known to occur on different hosts, but recent studies (Huanraulek et al., 2019) show that the species in its wide sense is probably polyphyletic. Further taxonomical studies are needed to resolve the species delimitation within Pyrenidium actinellum complex.

! $\dagger$ Ramalina dilacerata (Hoffm.) Hoffm. - coll. LF: on bark of Populus balsamifera, 09.06.1938 (Fagerström, 1945; Ahlner, 1948; H 8003328, 8003329). EN, 2 (Red..., 2018). 
Ramalina farinacea (L.) Ach. - on bark of Alnus incana, Padus avium, Populus tremula, and Salix sp.; 3, 14, 15 [R]. Coll. LF: on bark of Populus tremula, 09.06.1938 (H 8003355).

RAMALINA FRAXINEA (L.) Ach. - on bark of Populus alba L. and P. tremula; 14, 15 [R]. Coll. LF: on bark of Acer platanoides, 09.06.1938 (H 8003407).

! Ramalina SinEnsis Jatta - on bark of Populus tremula; $15\left[\mathrm{R}_{1}\right]$. Coll. LF: on bark of $P$. balsamifera and P. tremula, 09.06.1938 (H 80034398003442). EN, 2 (Red..., 2018).

Rhizocarpon badioatrum (Flörke ex Spreng.) Th. Fr. - on granite; $12\left[\mathrm{R}_{1}\right]$.

RHIZOCARPon CINEREOVIRENS (Müll. Arg.) Vain. - on granite; $7\left[\mathrm{R}_{1}\right]$. - New to $\mathrm{SPb}$, previously known from WLR (Stepanchikova et al., 2017).

RHIZOCARPON DISTINCTUM Th. Fr. - on granite; 1 , a4 [R].

RHIZOCARPON GRANDE (Flörke ex Flot.) Arnold - on granite; $12\left[\mathrm{R}_{1}\right]$.

Rhizocarpon laVATUM (Fr.) Hazsl. - on granite; $1,7,9,12[\mathrm{O}]$.

RHIZOCARPON MACROSPORUM Räsänen - on granite; $12\left[\mathrm{R}_{1}\right]$.

RHIZOCARPON REDUCTUM Th. Fr. - on granite; 14, a4 [R].

Ropalospora VIRIDIS (Tønsberg) Tønsberg - on bark of Acer platanoides, Alnus incana, Betula sp., and Populus tremula; 15, 16 [R].

SAGEdia zONATA Ach. - on granite; 7 [ $\left.\mathrm{R}_{1}\right]$.

+ SAREA Difformis (Fr.) Fr. - on resin of Picea abies and Pinus sylvestris; 4, 6, 9, 14, 16 [O].

+ SAREa REsinae (Fr.) Kuntze - on resin of Picea abies and Pinus sylvestris; 4, 8, 16 [R].

Scoliciosporum Chlorococcum (Graewe ex Stenh.) Vězda - on bark of Betula sp., Corylus avellana, Juniperus communis, Picea abies, Pinus sylvestris, Populus tremula, Salix sp., and Sorbus aucuparia, on wood; 1-4, 6, 12-14 [F].

SCOLICIOSPORUM SAROTHAMNI (Vain.) Vězda - on bark of Betula sp., Corylus avellana, Juniperus communis, Malus domestica, Padus avium, Picea abies, Pinus sylvestris, Populus tremula, Salix sp., and Sorbus aucuparia, on wood of Pinus sylvestris; 1-5, 8, 11-15 [C].
Scoliciosporum umbrinum (Ach.) Arnold - on granite; $12\left[R_{1}\right]$.

!* Scytinium teretiusculum (Wallr.) Otálora et al. - on bark of Populus tremula; $12\left[\mathrm{R}_{1}\right]$. CR, 1 (Red..., 2018).

Steinia Geophana (Nyl.) Stein - on sandy soil; a1, a4 [R].

+ Stenocybe Pullatula (Ach.) Stein - on bark of Alnus incana; $15\left[\mathrm{R}_{1}\right]$.

STEREOCAULON ALPINUM Laurer - on sandy soil; $1,10[R]$.

STEREOCAULON CONDENSATUM Hoffm. - on soil; $2\left[\mathrm{R}_{1}\right]$.

Stereocaulon SAXATILE H. Magn. - on burnt wood, granite, and slate; 7, 9, 10, a4 [R].

Stereocaulon taeniarum (H. Magn.) Kivistö - on primary soil; $12\left[\mathrm{R}_{1}\right]$. - New to $\mathrm{SPb}$, previously known from WLR (Stepanchikova et al., 2019).

Stereocaulon tomentosum Fr. - on soil; $2\left[\mathrm{R}_{1}\right]$. Coll. V. P. Drobov \& B. O. Kashmensky (Vereitinov \& Kashmensky, 1907).

STRANGOSPORA MORIFORMIS (Ach.) Stein - on bark of Pinus sylvestris; $12\left[\mathrm{R}_{1}\right]$.

Thelenella PeRTUSARIELla (Nyl.) Vain. - on bark of Sorbus aucuparia; $14\left[\mathrm{R}_{1}\right]$.

Thelidium MinUtUlum Körb. - on granite and concrete; 9, a1 [R].

TONINIA POPULORUM (A. Massal.) Kistenich et al. on bark of Populus tremula; $15\left[\mathrm{R}_{1}\right]$.

TONINIOPSIS SUBINCOMPTA (Nyl.) Kistenich et al. - on bark of Populus tremula; 14, 15 [R].

TRAPElia Glebulosa (Sm.) J. R. Laundon - on brick; $12\left[\mathrm{R}_{1}\right]$.

Trapelia Placodioides Coppins \& P. James - on granite; 7, 9, 14, a4 [R].

Trapeliopsis flexuosa (Fr.) Coppins \& P. James on bark of Betula sp., Picea abies, and Pinus sylvestris, on wood; 1-6, 9-14 [C].

TRAPELIOPSIS GRANUlOSA (Hoffm.) Lumbsch - on bark of Juniperus communis, on wood, soil, and decaying leather; 2, 9, 10, 14, a6 [O].

\# Tremella Cladoniae Diederich \& M. S. Christ. on thallus of Cladonia chlorophaea s. lat. on bark of Populus tremula; $12\left[\mathrm{R}_{1}\right]$. 
\# Tremella lichenicola Diederich - on thalli of Violella fucata on bark of Betula sp., Picea abies, Sorbus aucuparia, and wood of Pinus sylvestris; 8, 12, 13, 16 [O].

TuCKERMANNOPSIS CHLOROPHYLLA (Willd. ex Humb.) Hale - on bark of Betula sp., Juniperus communis, Padus avium, Picea abies, Pinus sylvestris, Salix sp., and Sorbus aucuparia, on wood of conifers; 1-3, 8, 9, 11, 12, 14-16 [C].

UMBILICARIA DEUSTA (L.) Baumg. - on granite; 12, a4 [R].

$\dagger$ Usnea barbata (L.) F. H. Wigg. - coll. LF: on bark of Acer platanoides, Betula sp., and Sorbus aucuparia, 09.06.1938 (H s. n.).

UsNeA DASOPOGA (Ach.) Nyl. - on bark of Populus tremula; $2\left[\mathrm{R}_{1}\right]$. Coll. LF (Fagerström, 1945).

$\dagger$ Usnea Glabrescens (Nyl. ex Vain.) Vain. ex Räsänen - coll. LF: on bark of Populus tremula, 09.06.1938 (Fagerström, 1945; H 8003633).

USNEA HIRTA (L.) F. H. Wigg. - on bark of Pinus sylvestris; $11\left[\mathrm{R}_{1}\right]$. Coll. LF: on bark of Acer platanoides, Betula sp., Populus balsamifera, P. tremula, and Sorbus aucuparia, 09.06.1938 (Fagerström, 1945; H 8003655-8003658, 8003673).

$\dagger$ UsNea LAPPONICA Vain. - coll. LF: on bark of Sorbus aucuparia, 09.06.1938 (H 8003683).

$\dagger$ UsNea sUbFloridana Stirt. - coll. LF: on bark of Acer platanoides, Betula sp., Populus balsamifera, P. tremula, and Sorbus aucuparia, 09.06.1938 (Fagerström, 1945, as Usnea similis (Mot.) Räs.; Halonen et al., 1999; H 8003696, $8003697,8003701,8003702$, 80037078003709).

$\dagger$ USNEA WASMUTHII Räsänen - coll. LF: on bark of Populus balsamifera, 09.06.1938 (H 8003732).

VERRUCARIA BOBLENSIS Servit - on concrete; $2\left[R_{1}\right]$. Det. Juha Pykälä, 2013.

VERRUCARIA MURALIS Ach. - on concrete; 2 [ $\left.R_{1}\right]$. Det. Juha Pykälä, 2016.

VERRUCARIA XYLOXENA Norman - on primary soil; a1 $\left[R_{1}\right]$.

Vezdaea ACICUlaris Coppins - on sand; $1\left[\mathrm{R}_{1}\right]$.

Vezdaea Retigera Poelt \& Döbbeler - on sand, soil, and on decaying thallus of Peltigera didactyla; 2, a1 [R].
Violella fucata (Stirt.) T. Sprib. - on bark of Betula sp., Padus avium, Picea abies, Pinus sylvestris, and Sorbus aucuparia, on wood of conifers; 1, 3, 5, 6, 8, 9, 12, 13, 15, 16 [C].

VULPICIDA PINASTRI (Scop.) J.-E. Mattsson \& M. J. Lai - on bark of coniferous and deciduous trees, on wood, and granite; 1-5, 7-16 [VC].

Xanthoparmelia Conspersa (Ehrh. ex Ach.) Hale on granite; 10, a4 [R].

XANThORIA PARIETina (L.) Th. Fr. - on bark of Malus domestica, Populus tremula, and Sorbus aucuparia; 2, 3, 12, 14, 15 [O].

Xylographa Parallela (Ach.) Fr. - on wood of Pinus sylvestris (roots of old pine); a6 $\left[\mathrm{R}_{1}\right]$.

XYlopsora friesil (Ach.) Bendiksby \& Timdal on bark of Picea abies and Pinus sylvestris; 4, 13, $16[R]$.

\section{Excluded and dubious taxa}

Bryoria implexa (Hoffm.) Brodo \& D. Hawksw. reported by Fagerström (1945) from bark of Sorbus aucuparia, but the specimen was not found. All available specimens by the same author from other areas within the Kurortny District of $\mathrm{SPb}$ were re-identified as other species of the genus (see Stepanchikova et al., 2020).

The currently known lichen diversity of the proposed protected area Pukhtolova Gora has a total of 252 species, including 232 lichenized, 12 lichenicolous and 8 non-lichenized saprobic fungi. Micarea laeta, M. pusilla, and Pyrenidium actinellum are new to North-Western European Russia; Parmelia serrana, Rhizocarpon cinereovirens, and Stereocaulon taeniarum are new to St. Petersburg.

Altogether 13 red-listed (Red..., 2018) species were recorded in the study area, with two of them known only from historical collections. Eight species previously recorded in Puhtolova Gora were not found in course of the last inventory: Anaptychia ciliaris, Evernia mesomorpha, Ramalina dilacerata, Usnea barbata, U. glabrescens, U. lapponica, U. wasmuthii. All these species are macrolichens, easy to find, and relatively sensitive to air pollution; they probably became extinct in the study area because of air pollution and disturbance of the forest communities. 
Pukhtolova Gora remains a well-preserved forest territory within the city limits, and its lichen biota nowadays is one of the richest in St. Petersburg. The contemporary lichen biota of Pukhtolova Gora counts 244 species. This number was higher than in all other protected territories of St. Petersburg, except for Gladyshevsky protected area (Stepanchikova et al., 2014). The majority of the species in the study area occurred rarely [R] (169 species, 69.3\%), 95 of which were recorded only once $\left[R_{1}\right]$, while 40 species $(16.4 \%$ of the lichen flora) were occasional $[\mathrm{O}], 16$ species $(6.6 \%)$ frequent $[\mathrm{F}]$, 11 species $(4.5 \%)$ common $[\mathrm{C}]$, and 8 species (3.3\%), namely Cladonia chlorophaea s. lat., C. coniocraea, Hypocenomyce scalaris, Hypogymnia physodes, Lecidea nylanderi, Parmeliopsis ambigua, Platismatia glauca, Vulpicida pinastri, were very common [VC].

An average amount of species per standard SA was $49.7 \pm 5.5$, with minimum 26 (anthropogenic community, SA 7), and maximum 99 species (mixed forest, SA 12). The number of species per SA was predictably higher than in more disturbed territories along the seashore (Stepanchikova et al., 2020). However, it is high even compared to the other protected areas of Kurortny District which are also remote from the city and covered with forests, and even compared to relatively well-preserved areas outside St. Petersburg. For example, the same character for the nearby Gladyshevsky protected area was

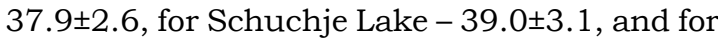
Smorodinka River valley (border of Priozersk and

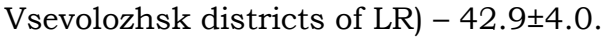

Most lichens in Pukhtolova Gora grew on tree bark (149 species, $61.1 \%$ of the modern lichen biota), and preferred phorophytes were aspen (72 species, $29.5 \%$ of the modern lichen biota), pine (66 species, 27.0\%), and birch (56 species, $23.0 \%$ ). Lichens were quite common also on wood (73 species, 29.9\%). The diversity of species inhabiting soil and plant debris was smaller (49 species, 20.1\%). Saxicolous lichens were not very diverse as well, being 46 species (18.9\% of the lichen diversity) in total: 37 species $(15.2 \%)$ were recorded on granite, and 12 species $(4.9 \%)$ on artificial substrates - concrete, brick, and slate. Thirteen species $(5.3 \%)$ of lichenicolous fungi were recorded. In addition to the listed substrates, some species were also found on mosses ( 5 species), leather (4 species), resin ( 2 species), and fruit bodies of polypores (1 species).

Most widespread in the study area were pine forests; these forests had moderately rich lichen biota (107 lichen species, $43.9 \%$ of the present-day lichen diversity of the study area). However, the richest communities with 150 species recorded $(61.5 \%$ of the lichen biota) were the less common mixed forests. Anthropogenic habitats, such as rubbish dumps, old foundations, roadside boulders and glades also showed remarkable lichen diversity (118 species, $48.4 \%$ of the lichen biota).

The lichens of spruce forests were not very diverse and represented by 69 species $(28.3 \%$ of the present-day lichen biota). Spruce stands in Pukhtolova Gora were mostly young or middleaged, however, there were small pieces of relatively undisturbed wet spruce forests in lowlands. Several indicator species of biologically valuable forests (Andersson et al., 2009), namely Chaenotheca stemonea, Chaenothecopsis nigra, Cladonia norvegica, and Microcalicium ahlneri, were found in one site (sample area 16). This site was represented by relatively undisturbed swampy spruce forest, which was quite unique for the territory of the megapolis. Such communities are almost absent now in the southern part of the Karelian Isthmus, both due to cuttings during the whole 20th century and to the development of the city suburbs. However, small wet lowlands around swamps and in river valleys were rarely subjected to cuttings and were not suitable for building, therefore these locations remained untouched even near huge cities, and so far, they might become local "biodiversity hot spots".

\section{ACKNOWLEDGEMENTS}

The authors are grateful to the Directorate of Nature Protected Areas of St. Petersburg, as well as to V. N. Khramtsov and E. A. Volkova (Komarov Botanical Institute of RAS, St. Petersburg) for support in organization of field studies. Sincere thanks to Teuvo Ahti (University of Helsinki) for his kind assistance during our work in $\mathrm{H}$. We appreciate the help of colleagues in $\mathrm{H}$ and $\mathrm{S}$ during our work in herbaria. The authors also thank the Reviewers and Editors for valuable recommendations. The study was supported by Russian Foundation for Basic Research (grant 20-0400473) and carried out within the framework 
of the institutional research project "Flora and systematics of algae, lichens, and bryophytes of Russia and phytogeographically important regions of the world" (no. 121021600184-6) of the Komarov Botanical Institute of the Russian Academy of Sciences.

\section{REFERENCES}

Ahlner, S. 1948. Utbredningstyper bland nordiska barrträdslavar. Acta Phytogeographica Suecica 22: 1-257.

Andersen, H. L. \& Ekman, S. 2005. Disintegration of the Micareaceae (lichenized Ascomycota): a molecular phylogeny based on mitochondrial rDNA sequences. Mycological Research 109: 21-30. https:/ / doi.org/ 10.1017/s0953756204001625

Andersson, L., Alexeeva, N. M. \& Kuznetsova, E. S. (eds). 2009. Survey of biologically valuable forests in North-Western European Russia. Vol. 2. Identification manual of species to be used during survey at stand level. St. Petersburg. 258 pp. (In Russian).

Coppins, B., Kashiwadani, H., Moon, K., Spribille, T. $\&$ Thor, G. 2021. The genera Brianaria (Psoraceae) and Micarea (Pilocarpaceae) in Japan, with reports on other interesting species in Asia. The Lichenologist 53(1): 35-44. https://doi.org/10.1017/ S0024282920000468

Czarnota, P. 2007. The lichen genus Micarea (Lecanorales, Ascomycota) in Poland. Polish Botanical Studies 23: 1-199.

Fagerström, L. 1945. Ett bidrag till kännedomen om lavfloran i Terijoki socken på Karelska näset. Memoranda Societatis pro Fauna et Flora Fennica 20: 155-170.

Himelbrant, D. E., Stepanchikova, I. S. \& Kuznetsova, E. S. 2005. The lichens. In: Volkova, E. A., Isatchenko, G. A. \& Khramtsov, V. N. (eds). Yuntolovsky Regional Complex Natural Reserve. St. Petersburg, pp. 133-140. (In Russian).

Himelbrant, D. E., Stepanchikova, I. S., Chesnokov, S. V., Konoreva, L. A., Rodionova, A. A., Kuznetsova, E. S. \& Schiefelbein, U. 2021. New records of lichens and allied fungi from the Leningrad Region, Russia. XI. Folia Cryptogamica Estonica 58. (In press).

Huanraulek N., Ertz D., Phukhamsakda C., Hongsanan S., Jayawardena R. S. \& Hyde K. D. 2019. Mycosphere 10: 634-654. https://doi. org/10.5943/mycosphere/10/1/13

Kantelinen, A., Westberg, M., Owe-Larsson, B. \& Svensson, M. 2021. New Micarea records from Norway and Sweden and an identification key to the M. prasina group in Europe. Graphis Scripta 33(2): 17-28.

Khramtsov, V. N. (ed.). 2021. Materials of the comprehensive environmental survey of the territory "Pukhtolova Gora". Report under the state contract
No. 47/20 dated 9.06.2020 for the comprehensive environmental survey of the St. Petersburg area. St. Petersburg. 160 pp. (In Russian).

Kotiranta, H., Uotila, P., Sulkava, S. \& Peltonen, S.-L. (eds). 1998. Red Data Book of East Fennoscandia. Helsinki. 351 pp.

Launis, A., Pykälä, J., Boom, P. van den, Sérusiaux, E. \& Myllys, L., 2019. Four new epiphytic species in the Micarea prasina group from Europe. The $L i-$ chenologist 51(1): 7-25. https://doi.org/10.1017/ S0024282918000555

Navarro-Rosines, P. \& Roux, C. 2007. Pyrenidium. Flora of the Greater Sonoran Desert Region. Vol. 3. Tempe, Arizona, pp. 404-405.

Nordin, A., Moberg, R., Tønsberg, T., Vitikainen, O., Dalsätt, Å., Myrdal, M., Snitting, D. \& Ekman, S. 2011. Santesson's Checklist of Fennoscandian Lichen-forming and Lichenicolous Fungi. Ver. April 29, 2011 - http://130.238.83.220/santesson/ home.php (1 March 2021).

Orange, A., James, P. W. \& White, F. J. 2001. Microchemical methods for the identification of lichens. London. $101 \mathrm{pp}$.

Red Data Book of St. Petersburg. 2018. St. Petersburg. 568 pp. (In Russian).

Stepanchikova, I. S., Andreev, M. P., Himelbrant, D. E., Motiejūnaitè, J., Schiefelbein, U., Konoreva, L. A. \& Ahti, T. 2017. The lichens of Bolshoy Tuters Island (Tytärsaari), Leningrad Region, Russia. Folia Cryptogamica Estonica 54: 95-116. https:/ / doi.org/10.12697/fce.2017.54.14

Stepanchikova, I. S., Himelbrant, D. E. \& Konoreva, L. A. 2014. The lichens and allied fungi of the Gladyshevsky Protected Area (Saint Petersburg). Novosti sistematiki nizshikh rastenii 48: 291-314. https://doi.org/10.31111/nsnr/2014.48.291

Stepanchikova, I. S., Himelbrant, D. E., Kuznetsova, E. S., Motiejūnaitè, J., Chesnokov, S. V., Konoreva, L. A. \& Gagarina, L. V. 2020. The lichens of the northern shore of the Gulf of Finland in the limits of St. Petersburg, Russia - diversity on the edge of megapolis. Folia Cryptogamica Estonica 57: 101132. https:/ / doi.org/10.12697/fce.2020.57.11

Stepanchikova, I. S., Himelbrant, D. E., Schiefelbein, U., Motiejūnaitè, J., Ahti, T. \& Andreev, M. P. 2019. The lichens of Moshchny Island (Lavansaari) - one of the remote islands in the Gulf of Finland. Folia Cryptogamica Estonica 56: 31-52. https:/ / doi.org/10.12697/fce.2019.56.05

Vereitinov, I. A. \& Kashmensky, B. O. 1907. School herbarium of the cryptogamic plants. Issue 1. List of lichens. Yur'ev. 7 pp. (In Russian).

Zhurbenko, M. P. \& Pino-Bodas, R. 2017. A revision of lichenicolous fungi growing on Cladonia, mainly from the Northern Hemisphere, with a worldwide key to the known species. Opuscula Philolichenum 16: $188-266$.

Zhurbenko, M. P. 2004. Lichenicolous and some interesting lichenized fungi from the Northern Ural, Komi Republic of Russia. Herzogia 17: 77-86. 
Appendix 1. List of the studied locations in Puhtolova Gora proposed protected area, Kurortny District, St. Petersburg

\begin{tabular}{|c|c|c|}
\hline No & Description, geographical coordinates, biotope, collectors & Date \\
\hline & Standard sample areas: & \\
\hline 1 & $\begin{array}{l}\text { E part of the study area, NW slope of Pukhtolova hill (former Puhtulanmäki), } 60^{\circ} 13^{\prime} 49^{\prime \prime} \mathrm{N} \text {, } \\
29^{\circ} 40^{\prime} 39^{\prime \prime} \mathrm{E} \text {, disturbed blueberry-moss pine forest on the slope. DH, EK, IS. }\end{array}$ & $\begin{array}{l}22.05 .2010 \\
31.10 .2020\end{array}$ \\
\hline 2 & $\begin{array}{l}\text { E part, the central artillery nest NW of Pukhtolova hill, } 60^{\circ} 14^{\prime} 01^{\prime \prime} \mathrm{N}, 29^{\circ} 40^{\prime} 23^{\prime \prime} \mathrm{E} \text {, anthropogenic } \\
\text { meadow with single trees surrounded by disturbed blueberry-moss pine forest. DH, EK, IS. }\end{array}$ & 22.05 .2010 \\
\hline 3 & $\begin{array}{l}\text { E part, W shore of Lake Ilistoe (former Likolampi) } \mathrm{N} \text { of Pukhtolova hill, } 60^{\circ} 14^{\prime} 04^{\prime \prime} \mathrm{N} \text {, } \\
29^{\circ} 40^{\prime} 43^{\prime \prime} \mathrm{E} \text {, mixed ash-aspen-willow community with pine and apple trees on the shore of the } \\
\text { lake. DH, EK, IS. }\end{array}$ & 22.05 .2010 \\
\hline 4 & $\begin{array}{l}\text { W part, S of Roshchino (former Raivola), } 60^{\circ} 14^{\prime} 03^{\prime \prime} \mathrm{N}, 29^{\circ} 37^{\prime} 19^{\prime \prime} \mathrm{E} \text {, spruce-pine moss-blueberry } \\
\text { forest with single rowans and shrubs of hazel. DH, EK. }\end{array}$ & 23.05 .2010 \\
\hline 5 & $\begin{array}{l}\text { W part, S of Roshchino, } 60^{\circ} 13^{\prime} 56^{\prime \prime} \mathrm{N}, 29^{\circ} 36^{\prime} 55^{\prime \prime} \mathrm{E} \text {, blueberry-moss pine forest with young } \\
\text { spruces and juniper. DH, EK. }\end{array}$ & 23.05 .2010 \\
\hline 6 & $\begin{array}{l}\text { W part, S of Roshchino, } 60^{\circ} 13^{\prime} 59^{\prime \prime} \mathrm{N}, 29^{\circ} 38^{\prime} 06^{\prime \prime E} \text {, moss-blueberry birch-spruce forest, in places } \\
\text { with Sphagnum spp. DH, EK. }\end{array}$ & 23.05 .2010 \\
\hline 7 & $\begin{array}{l}\text { W part, S of Roshchino, NE of the old sand pit near the Roshchinskoe highway, } 60^{\circ} 13^{\prime} 48^{\prime \prime} \mathrm{N} \text {, } \\
29^{\circ} 37^{\prime} 35^{\prime} \mathrm{E} \text {, an old foundation of granite blocks and a dugout surrounded by a blueberry pine } \\
\text { forest. DH, EK. }\end{array}$ & 23.05 .2010 \\
\hline 8 & $\begin{array}{l}\text { Central part, valley of the small stream, } 60^{\circ} 13^{\prime} 57^{\prime \prime} \mathrm{N}, 29^{\circ} 38^{\prime} 42.5^{\prime \prime} \mathrm{E} \text {, blueberry-moss spruce } \\
\text { forest. DH, IS. }\end{array}$ & 29.05 .2010 \\
\hline 9 & $\begin{array}{l}\text { Central part, S of the power line, } 60^{\circ} 14^{\prime} 17^{\prime \prime} \mathrm{N}, 29^{\circ} 38^{\prime} 50^{\prime \prime} \mathrm{E} \text {, open blueberry-lichen-moss pine } \\
\text { forest. DH, IS. }\end{array}$ & 29.05 .2010 \\
\hline 10 & $\begin{array}{l}\text { Central part, S of the Lake Belets (former Valklampi), } 60^{\circ} 14^{\prime} 29^{\prime \prime} \mathrm{N}, 29^{\circ} 38^{\prime} 51^{\prime \prime} \mathrm{E} \text {, anthropogenic } \\
\text { habitat (dump). DH, IS. }\end{array}$ & 29.05 .2010 \\
\hline 11 & $\begin{array}{l}\text { Central part, swamp SWW of the Lake Krugloe (former Kaskijärvi), } 60^{\circ} 14^{\prime} 20^{\prime \prime} \mathrm{N}, 29^{\circ} 39^{\prime} 35^{\prime \prime} \mathrm{E} \text {, } \\
\text { cottongrass-sphagnum swamp with standing pine deadwood. DH, IS. }\end{array}$ & 29.05 .2010 \\
\hline 12 & $\begin{array}{l}\text { E part, SW of artillery nests, } 60^{\circ} 13^{\prime} 58^{\prime \prime} \mathrm{N}, 29^{\circ} 40^{\prime} 14^{\prime \prime} \mathrm{E} \text {, sparse disturbed aspen-birch forest with } \\
\text { juniper. DH, EK, IS. }\end{array}$ & 30.05 .2010 \\
\hline 13 & $\begin{array}{l}\text { Central part, SW of the Lake Krugloe, } 60^{\circ} 14^{\prime} 11^{\prime \prime} \mathrm{N}, 29^{\circ} 39^{\prime} 53^{\prime \prime} \mathrm{E} \text {, blueberry-moss pine forest. } \\
\text { DH, EK, IS. }\end{array}$ & 30.05 .2010 \\
\hline 14 & $\begin{array}{l}\text { Central part, the top of a small hill, } 60^{\circ} 13^{\prime} 45.5^{\prime \prime} \mathrm{N}, 29^{\circ} 39^{\prime} 29.0^{\prime \prime} \mathrm{E} \text {, pine-aspen-birch forest. } \\
\text { DH, EK, IS. }\end{array}$ & 30.05 .2010 \\
\hline 15 & $\begin{array}{l}\text { W part, } S \text { vicinity of Roshchino, } 60^{\circ} 14^{\prime} 01.6^{\prime \prime} \mathrm{N}, 29^{\circ} 36^{\prime} 50.7^{\prime \prime} \mathrm{E} \text {, local lowland, damp horsetail-fern } \\
\text { birch-aspen forest with grey alder and maple, with fallen trees. DH, IS. }\end{array}$ & 31.10 .2020 \\
\hline \multirow[t]{2}{*}{16} & $\begin{array}{l}\text { Central part, lowland } \mathrm{N} \text { of the Roshchinskoe highway, } 60^{\circ} 13^{\prime} 48.7^{\prime \prime} \mathrm{N}, 29^{\circ} 38^{\prime} 43.7^{\prime \prime} \mathrm{E} \text {, relatively } \\
\text { undisturbed middle-aged swampy sphagnum spruce forest with birch. DH, IS. }\end{array}$ & 31.10 .2020 \\
\hline & Additional plots: & \\
\hline a1 & $\begin{array}{l}\text { Central part, near the Roshchinskoe highway, } 60^{\circ} 13^{\prime} 45^{\prime \prime} \mathrm{N}, 29^{\circ} 38^{\prime} 24.5^{\prime \prime} \mathrm{E} \text {, old concrete blocks } \\
\text { near a dirt road surrounded by a disturbed pine forest. DH, IS. }\end{array}$ & 29.05 .2010 \\
\hline $\mathrm{a} 2$ & $\begin{array}{l}\text { Central part, valley of a small stream, } 60^{\circ} 14^{\prime} 10^{\prime \prime} \mathrm{N}, 29^{\circ} 38^{\prime} 39^{\prime \prime} \mathrm{E} \text {, a trampled path in pine forest } \\
\text { with spruce. DH, IS. }\end{array}$ & 29.05 .2010 \\
\hline a3 & Central part, $60^{\circ} 13^{\prime} 56^{\prime \prime} \mathrm{N}, 29^{\circ} 39^{\prime} 02^{\prime \prime} \mathrm{E}$, cutline in pine forest with spruce. DH, IS. & 29.05 .2010 \\
\hline a4 & $\begin{array}{l}\text { Central part, SW of the Lake Krugloe, power line, } 60^{\circ} 144^{\prime} 09.5^{\prime \prime} \mathrm{N}, 29^{\circ} 39^{\prime} 24.0^{\prime \prime} \mathrm{E} \text {, a group of } \\
\text { boulders on a glade in pine forest and a dirt road. DH, EK, IS. }\end{array}$ & 30.05 .2010 \\
\hline a5 & E part, SW of the Lake Ilistoe, $60^{\circ} 13^{\prime} 56^{\prime \prime} \mathrm{N}, 29^{\circ} 40^{\prime} 39^{\prime \prime} \mathrm{E}$, dirt road. DH, EK, IS. & 22.05 .2010 \\
\hline a6 & $\begin{array}{l}\text { E part, Pukhtolova hill, S slope close to the top, } 60^{\circ} 13^{\prime} 47.1^{\prime \prime} \mathrm{N}, 29^{\circ} 40^{\prime} 53.6^{\prime \prime} \mathrm{E} \text {, disturbed blue- } \\
\text { berry-moss pine forest. DH, IS. }\end{array}$ & 31.10 .2020 \\
\hline a7 & $\begin{array}{l}\text { Central part, } \mathrm{N} \text { of the Roshchinskoe highway, } 60^{\circ} 13^{\prime} 48.8^{\prime \prime} \mathrm{N}, 29^{\circ} 38^{\prime} 30.6^{\prime \prime} \mathrm{E} \text {, middle-aged } \\
\text { lingonberry-moss pine forest. DH, IS. }\end{array}$ & 31.10 .2020 \\
\hline a8 & $\begin{array}{l}\text { E part, Pukhtolova hill, the lower part of the NE slope, } 60^{\circ} 13^{\prime} 51.2^{\prime \prime} \mathrm{N}, 29^{\circ} 40^{\prime} 47.5^{\prime \prime} \mathrm{E} \text {, a group } \\
\text { of young spruces in a blueberry-moss pine forest near the pond. DH, IS. }\end{array}$ & 31.10 .2020 \\
\hline
\end{tabular}

